\title{
Empiricist Interventions: Strategy and Tactics on the Ontopolitical Battlefield
}

\section{Anders Kristian Munk and Sebastian Abrahamsson}

Recent papers by prominent scholars in science and technology studies (notably John Law and Bruno Latour) have crystallized a fundamental disagreement about the scope and purpose of intervention in actor-network theory or what we here choose to bracket as empirical philosophy. While the precept of agnostic description is taken as a given, the desired effects of such descriptions are highly debated: Is the goal to interfere with the singularity of the real through the enactment of multiple and possibly conflicting ontologies? Or is it (also) to craft new and comprehensive common worlds supported by notions of due process and parliamentary procedure? In this paper we think about this disagreement as a question of research strategy (a normative discord about the desirable outcome of an intervention) in order to assess its implications for research tactics (a descriptive accord about the practical crafting of an adequate account). A key point here is to challenge the impermeability of such a division and show how the strategic dispute, if to be taken seriously, invariably spills over to swamp the level of tactics. To illustrate this point, we draw upon materials from our recent doctoral research projects and to facilitate the discussion we make two deliberate caricatures: Firstly, we operate with a simplified history of actor-network theory in which a strategy of epistemological critique has been replaced by two contending agendas for ontological intervention. Secondly, we address these two contending agendas as distinct options which map on to the positions of our two main interlocutors. In doing so, it becomes possible to compare their respective tactical implications as we work through two examples of what might constitute an empiricist intervention.

Keywords: intervention, empirical philosophy, compositionism

\section{Introduction}

A specter haunts not only Europe but the world: that of compositionism. All the Powers of the Modernist World have entered into a holy alliance to exorcise this specter! (Latour, 2010a: 474)
If we become constitutionalists we're losing location and specificity. We're losing contingency. We're adopting a particular political or legal mode of thinking about what it is to live well together. (...) And finally we're forgetting that rules and procedures do not actually rule: that in practice the world is irredeemably messy. (Law, 2009: 5) 
The claim that analysis should be treated as a form of intervention is by now well rehearsed within the strand of STS sometimes branded as empirical philosophy'. Thus, authors like John Law and Annemarie Mol have argued that methods work by performing realities rather than by reporting on them (e.g. Mol, 1999; Law, 2004a) and Bruno Latour has repeatedly stressed that good accounts rely on transformation rather than information (e.g. Latour, 1999; 2004a; 2004c).

While this line of reasoning has been both provoked and enriched by a wave of feminist and postcolonial critique of 'naïve' description and its tendency to privilege the already powerful while silencing the already marginal (e.g. Haraway, 1988; Star, 1991; Lee \& Brown, 1994), empirical philosophy has increasingly been thinking through its burgeoning commitment to politics on its own terms. The past two decades $^{2}$ have not only seen the idea of analysis as intervention gain prominence, they have also witnessed a fecund debate take shape around the means and virtues by which such interventions might be successfully carried out.

Before going any further it seems important to assert that the concept of intervention does not have to connote an actionoriented or participatory agenda, even though this is often the case. As Jessica Mesman points out in her account of a researching self positively dedicated to the engagement with, and transformation of, professional practice, 'research effectively intervenes [regardless of our intentions] by accepting, challenging or diversifying problem definitions of the actors we study' (Mesman, 2007: 281). This is a particularly relevant notion in the context of empirical philosophy where the issue of intervention is cast in terms of description: what do to with it/expect from it and how to handle the various forms of politics and resistance confronting it (see especially Vikkelsø, 2007).

Our focus in this paper thus renders the concept of intervention in a very specific format which is not necessarily amenable to all aspects of the wider and somewhat more action-oriented debates on the topic which are currently taking place within STS (for an overview see for example Zuiderent-Jerak \& Jensen, 2007; or Cohen \& Galusky, 2010). Put crudely, to empirical philosophy the main concern with intervention seems to be how to make research relevant to practitioners while simultaneously insisting on an agnostically descriptive position which could easily be construed as being somewhat on (if not way out over) the sideline of the events in which the said practitioners are caught up. At least two strategic alternatives are emerging in response to this concern.

\section{Lining up the Armies: Two Strategies for Intervention}

With his 'compositionist manifesto', Bruno Latour (2010a) has resuscitated the grand narrative style and called for us to engage in 'cosmopolitics': the meticulous work of crafting a comprehensive common world (Latour, 2004d; following Stengers, 2003a; 2003b); of 'reassembling' instead of debunking (Latour, 2005b). This quest not only requires careful attention to 'matters of concern' rather than hasty allusions to 'matters of fact' (Latour, 2003), but also new versions of parliamentary essentials such as due process and constitutional order (Latour, 2004b).

John Law, on the other hand, has explicitly abstained from pledging any normative or procedural allegiances, what he with a polemic stroke calls 'constitutionalism' (Law, 2009) ${ }^{3}$, insisting instead that STS should rely on its attention to the multiplicity of situated experience and focus 
on the difference it can make by describing/enacting these messy specificities (e.g. Mol, 2002; Moser, 2008). Although immune to any talk of parliaments and common worlds, this approach is still engaged in politics through its commitment to undoing the singularity of the real. Rather than due process and careful assemblage the keyword here is 'interference' (Law, 2004b; 2009; following Haraway, 1989; 1991).

Arguably, then, there is a (somewhat caricatured) choice to be made for the empiricist scholar keen to treat analysis as intervention: unite under the compositionist banner, or join the guerrilla of ontological interference ${ }^{4}$. In this paper we unpack that choice by drawing upon two recent field experiences: one is concerned with the mummified body of an Egyptian boy and the converging visual practices of art and science (Abrahamsson, 2010a); the other with the illusive phenomenon of flood risk and an unfolding public knowledge controversy in the UK (Munk, 2010). One played out in historical archives, a museum, radiological wards and an art gallery; the other in the offices of flood modelling consultancies and insurance companies.

Their obvious differences aside, they were both wrestling with a commitment to empirical philosophy and flagged up some of the practical implications of trying to make a strategic choice between composition and interference. In retrospect they raise questions about the kind of interventions we might hope to make and the relationship between such hopes and the more mundane choices that mark up the daily pace of a doctoral research project: choices about how and where to ask what kind of questions, and choices about what to do with the materials these questions generate. Surely, faced with the option of crafting commonality or enacting disparity, a choice must somehow be made. What we want to discuss here, however, is the tactical arsenal available to support either of these strategic alternatives, let alone deciding between them.

The military lingo is deliberate. It is intended as a way of recasting the partition between normative questions regarding interventionist ambitions and methodological questions regarding the practicalities of description. As such the battlefield refers broadly to the ontopolitics of any effort (research related or not) struggling to define what is at stake in a given issue and should not be read specifically as a metaphor for the intellectual debate taking place between the main interlocutors of this paper (Law and Latour) ${ }^{5}$. By referring to our daily research practices as 'tactics' and the interventionist programmes under consideration as 'strategies' we are simply reminding ourselves of a difference between 'the theory of the use of military forces in combats' and 'the theory of the use of combats for the object of the war' (Clausewitz, 2008: 89). We are in other words trying to make a distinction between the received wisdom on how to conduct research in the tradition of empirical philosophy, and the shifting motivations for doing so in the first place. At the same time we are also interested in the practical impossibility of such a distinction, noting that if 'Strategy forms the plan of the War (...) it follows, as a matter of course, that Strategy must go with the Army to the field in order to arrange particulars' (Clausewitz, 2008: 147).

However dissimilar in scope, the strategic alternatives of compositionism and ontological interference have both been fashioned from the same core fibre of ideas: their respective protagonists cite the annals of actor-network theory (before and after) extensively in support of their differing ambitions (compare for example Latour, 2005b: 258-262 with Law, 2009) 
and thus rely on much of the same weaponry, and many of the same manoeuvres, for carrying out their operations. Working through our examples, we will take this shared tactical arsenal into account in order to become attentive to the ways in which it supports, complicates, or possibly obstructs the contending plans for the war effort. We want to do that by inspecting three basic tenets of what we consider to be empiricist research tactics.

\section{Battlefield Awareness: What kind of Questions to Ask?}

The first of these tenets has to do with the operational theatre in which empirical philosophy sees combat (intervenes, that is) and our attention to the challenges it poses. We could call it battlefield awareness. Taking Annemarie Mol's definition of 'ontological politics' as a useful starting point, it is a theatre in which 'the conditions of possibility are not given' and hence a theatre in which 'reality does not precede the mundane practices in which we interact with it' (Mol, 1999: 75). That goes for our research practices as well and inevitably fosters the claim that description can be treated as a form of intervention, what John Law calls 'our own unavoidable complicity in reality making' (Law, 2004a: 154). Consequently, we are taught to nurture a basic uncertainty about what there is in the world and to ask questions which do not enforce particular conditions of possibility on whatever it is we are studying.

Isabelle Stengers compares this situation to that of the solitary huntsman who cannot rely on a pack of hounds to chase a targetable prey out into the open. Rather, he must take it upon himself to develop such a target in the interplay between his own subtlety and that of his prey. It is not simply a matter of taking aim and pulling the trigger, because the prey is never 'visible, panic-stricken, reduced to the channelled behaviour imposed on it by the pack' (Stengers, 1997: 129). On the contrary, if the prey appears visible and panic-stricken we are cautioned not to shoot offhand but to question instead how it has been made so. In practice that means not only that the laborious task of tracing associations through their specific locales should always have priority (this is generally agreed upon, compare for example Law, 2004a with Latour, 2005b), but that the questions we ask play a role in defining the kind of skirmishes we come to engage - what Doreen Massey refers to as the active process of 'imagining the field' (Massey, 2003) - and thus sets us on track down potentially very different interventionist avenues. In our respective efforts to become attentive to the battlefields in which we were about to intervene we felt logically compelled to ask open-ended questions, but as it turned out there were several ways of doing this, each of them offering their own strategic opportunities.

Our first example concerns the issue of inland flood risk in England and Wales, and in particular the provision of flood insurance. This is a highly controversial issue and has for the past decade been a matter of sustained public concern. This is not least due to the complex and changing makeup of a problem rooted in the transitive domain between science, politics, and the market; a problem ranging from weather phenomena to planning policies; and a problem riddled with the inherent uncertainties involved in trying to handle (i.e. simulate, estimate, price, trade, prevent, mitigate) events which have yet to take place. The evolving plethora of possible future floods circulating both the market place and the broader public domain under the auspices of hydraulic and financial models has considerable 'practical consequences' (James, 1987: 506) and 
makes just as much of a difference to the insurance market as do actual floods when they occur. But while it is of paramount importance to both homeowners, insurance companies and government agencies to know their flood risk, there seems to be no clear guide as to how this should be known and hence the unsettlement is pungent.

One way of mustering some ontological curiosity about this relationship between risk and controversy would be to question whether the lack of consensus simply concerns various ways of knowing the risk of flooding, or whether this variety of knowledge practices also implies a proliferation of different versions of flood risk itself. Understanding how flood risk becomes an object of controversy would, if this is the case, mean that we should ask how flood risk becomes several objects in the first place - how it becomes a 'coexistence of multiple entities that go by the same name' (Mol, 2002: 151) - and how the protagonists of the issue are thus no longer concerned with exactly the same thing.

That kind of curiosity allows the notion of controversy some potency by setting it firmly apart from mere disagreements and rectifiable misunderstandings. It also plays to the strategic imperative of ontological interference by promising to enact a multiplicity of realities which might not lend themselves in an equally ready manner to the formal politics of risk management. In a public discourse bent on reaching settlement through the procurement of clear and unambiguous information, the contribution of such an enquiry could actually be to bolster controversy and embrace it as a healthy expression of a world which is after all 'irredeemably messy' (Law, 2009: 5).

However, while such a project could probably be approved by the commanding officers of John Law's ontological guerrilla there is no guarantee that it would appeal to the compositionist commissary. If the aspiration is not only to '[multiply] the entities with which we are led to live', but also to '[decide] whether the assembled aggregates form a liveable world or not' (Latour, 2005b: 254), then it might require a different kind of curiosity to begin with.

The difference, it seems, lies not with the interest in multiplicity (that interest is conserved), but with the interest in normativity: the task of crafting a properly comprehensive common world can of course only be undertaken if the list of constituents to be comprised is already exhaustive (multiplicity), but it must also find ways of distinguishing 'good' from 'bad' constitutions (normativity). Some sense of cosmopolitical correctness is in other words needed to enact commonality in what could otherwise be taken (mistaken, perhaps) for irredeemable messiness. So, instead of asking what flood risk is (keeping open the conditions of possibility for a potentially multiple object), we might consider asking what it takes to be risking a flood (keeping open the conditions of possibility for a particular kind of assemblage and its heterogeneous constituency).

The promise of such an enquiry is not so much to enact multiple versions of what flood risk can be, as it is to explore what makes for well constructed flood risk and thus determine what it should be (in a cosmopolitically correct sense). We will explore some of the possible results of such an investigation later on, but for now it suffices to note that there are at least two distinct lines of enquiry to decide between.

Our second example concerns a mummified body from ancient Egypt. During the summer of 2008 it was on loan from a museum in the UK and exhibited in an art gallery in London. In that art gallery a range of other materials were on display next to it: sculptures made from CT-scans 
of the mummified remains; a documentary film about the sculpting artist's journey to the original burial place in Egypt; documents detailing a forensic analysis of the body; a booklet in which a museum curator had written about it; etc. Rather than reporting a single version of the main exhibit, or supplementing what science had already done to it, these materials conjured several contrasting, sometimes contradictory versions of what seemed to be one and the same thing, namely the mummified body itself.

In a similar manner to flood risk, albeit with very different implications, that body was enacted as 'many things and one' (Mol, 2002: 82): it had been made to witness about its past under the gaze of forensic, archaeological and medical science; it had been exhibited in museums as a material embodiment that shed light on a long gone civilization; its afterlife was part and parcel of the Egyptomania sweeping over Europe since the beginning of the 20th century. Tracing these complex histories might be considered a task for interventionist social science $^{6}$ - or, indeed, for interventionist exhibition practice - one possible outcome of which could be to foreground the 'elusive, ephemeral, and unpredictable' (Law \& Urry, 2004: 404) aspects of a body which is otherwise rendered as being in every way tangible, lasting and long since predicted. This kind of unravelling, then, would be specifically pitched against a predominant and singular ontology with which it would deliberately, as the main interventionist goal, attempt to interfere.

Again, there is another possible, and potentially quite different, way of approaching this enquiry. Contrary to the risk of flooding, a mummified body is precisely - and virtually by definition - a well-constructed and enduring object. What the Egyptians knew so well was that in order for the deceased to subsist, despite the gnawing teeth of time, he or she had to be prepared, embalmed, encapsulated in layers of wrappings and laid to rest in a still environment. In other words: for a body to become a mummified body it had to be carefully and properly made. An alternative way to proceed would be to ask how - considering the diverging orderings mentioned above - the body manages to subsist as 'one'? How does it hold together, how does it endure, how does it come to appear as singular?

Mummified bodies, like art and museum exhibitions, monuments or archives, are ways of organizing time and space in such a way that they appear as dead, immobile and still (Sloterdijk, 2009: 71-72): they are capsules of stability and order that humans invent 'to hold onto a world that always overwhelms their grasp' (Rose, 2002: 461, compare with Whitehead, 1926: 166 on Cleopatra's Needle). The mummified body was specifically designed to obstruct any attempt to unravel, deconstruct or multiply it. After all, unravelling the body, if we take this in a literal sense, would mean the end of it, as evidenced by the many (in)famous unrolling spectacles of mummies in the 19th century (Taylor, 1995).

In a new and comprehensive common world, to what role might such stabilities be assigned? Contemplating a somewhat similar exhibition (about the evolution of the science of the evolution of the horse) Latour notes that in order to 'convince the people to invest in the devising, upkeep and enlargement of the very humble means necessary to know something with objectivity' (Latour, 2007: 31) we need not only histories of knowledge, but also histories of what is being known. Perhaps, with a compositionist aspiration in mind, this is a more fruitful way to question what goes on in the art gallery: what, if we approach an enduring object with which we have to live together well, should an 
exhibition of a mummified body try to accomplish?

Contemplating both the exhibition of the mummy and the issue of flood risk it is possible to imagine several lines of enquiry which would all meet the challenges of an ontopolitical battlefield. However, each of them seems to promise different kinds of interventions, which suggests that it is not sufficient to approach an issue like the solitary huntsman approaches his latent prey, asking non-prescriptive questions, keeping open the conditions of possibility. Although this is still a core tactic we have to ask ourselves the additional question of exactly what kind of possibilities it is that we are trying so hard not to condition. Is it the multiplicity of objects like flood risk or mummies or is it their cosmopolitically correct constitutions we are keeping an open mind about? This reflection plays directly into the current strategic discord between the ontological guerrilla and the compositionist international since deciding what it is we are trying not to condition will have strategic consequences for the kind of interventions we can hope to carry out.

\section{Marksmanship: Where to Go and What to Describe?}

This leads us to the second tenet which has to do with the investigative techniques that we bring to bear on our emerging targets once the operational conditions have been acknowledged. We could call it marksmanship. It is frequently summed up in the simple maxim that we should be rigorously descriptive and it can be readily justified in battlefield awareness: to leave the conditions of possibility open implies a rejection of explanatory frameworks, what John Law calls 'the prescription to be nonprescriptive' (Law, 2009: 6; following Callon, 1986), and requires us instead to 'follow the actors themselves' (Latour, 2005b: 12) in order to find the 'uniquely adequate account of a given situation' (Latour, 2005b: 144).

Yet, if we acknowledge that a choice of interventionist strategy is already signalled in the questions we choose to ask, if we acknowledge that we cannot simply leave the conditions of possibility open but that we must to some extent be strategically reflexive as to what it is we are keeping them open for, then there could be consequences for our subsequent descriptions as well. Now that there are several possible and strategically different lines of enquiry available to us, the interesting question for this paper becomes how they influence our decisions about where to go and what to describe. What we want to argue here is that our choice of questions calibrates the descriptive work and the tactical doctrines informing it in very particular ways.

Let us start with the mummy this time since it represents a challenge of its own to this kind of descriptive marksmanship. Contrary to the brawling controversy about flood insurance it seems mute and, well, dead. How do you describe something which appears to have stopped happening? Arriving at this late stage when the exhibition has been assembled, the mummified body scanned and analysed by the forensic team, the body loaned by the museum, we may ask ourselves how this specific mummy, unearthed in Egypt more than 200 years ago, ended up right here, in an art gallery in London, and right now, in the summer of 2008 ?

A first option would be to trace actors in the past through archival material and textual references. Indeed, a lot of the associated material that is exhibited in the gallery pave the way for an intervention that could be construed as genealogical and archival, probing how, through different practices and in different situations, this 
body has been shaped and enacted differently. If, for a moment, we ignore that mute and dead 'body itself' and focus on those absent presences, this is what could happen: in the gallery space there are textual references to Flinders Petrie, the archaeologist who brought the mummy from the excavation site in Hawara in 1888; there are also the CT-scans, dated 2006 from a hospital in Oxford, that tell of the forensic analysis of the body; there are texts written by a museum curator about the historical specificity of the excavation; finally there is documentary material by the artist.

Seen through the lens of what we here call the ontological guerrilla the list of potential actors to follow proliferate: there are radiologists in the hospital that scanned the body; there is an archaeological excavation, and a historical record to analyze; there is a museum to visit, and a curator to interview; there is an artist and some documentary footage to engage with. And once we endeavour to do all of the above the list of possible leads expand further: the curator mentions an X-ray analysis of the body in the 1960's, and an archive where the X-ray plates are kept; engaging with the radiologists, it turns out, will require some familiarity with medical scanning and the particular configuration of vision that it implies; the historical record, and the specificities of the excavation site, will undoubtedly be messy and involve all sorts of detours.

Following this line of enquiry we might end up with many different situated enactments of the mummified body, each of them crafted in local and specific practices that operate more or less in isolation from one another. Along the way the radiologists that we interview will tell us that, for them, using a medical diagnostic tool, the body is transformed from a 'dry and dusty package' into a 'virtual model that can be navigated, copied and transported'. Mean- while, the museum curators will tell us that they knew 'virtually nothing about the mummy before the scan, except it comes from a village in Egypt called Hawara'. We will also learn that in spite of the momentary stir that the current exhibition has caused in local media, the archaeologist who is responsible for having brought the body to the UK did not show a lot of interest in this particular body, as evidenced by his excavation report (Petrie, 1889). In each of these sites and situations different versions of the body are made to exist. Pursuing this route we will have ended up with an account of different enactments of a particular bundle of bones and wrapping that we call the body: different entities that go by the same name.

In the above, what happens is that we show how the mummified body coexists with others and that the reality of such a body is to some degree multiple. In this enterprise, however, the body is literally left untouched. Rather, focus is on the ongoingness of practices and practitioners. But how does the 'body itself' figure in all of this? In the art gallery people come and go - surely - other bodies, those of the visitors, move around slowly and silently, looking at the objects on display; pointed lights illuminate the space in particular ways; flickering screens present visitors with images of Egypt on the one hand and moving CT-images from the radiological examination of the mummy on the other hand; meanwhile the buzzing noise from the street outside is kept at bay and the vibrant flow of the city is suspended. In this sense, the art gallery is a space not unlike the Egyptian tomb chambers: 'they too were designed to eliminate awareness of the outside world' and they too 'were chambers where an illusion of eternal presence was to be protected from the flow of time' (O’Doherty, 1986: 8). 
If we were to resist momentarily the urge to 'unravel' the mummified body and trace out its associations, this is what we are left with: a tomb-like exhibition, a 'deeply unrealistic' space in which 'the usual constraints of time, space, and realism are suspended' (Weibel \& Latour, 2007: 94). Compared with the highly controversial landscape of flood risk, there is very little happening in this exhibition space. On the other hand, considering the messy pasts of the body, the tranquillity is striking and cannot have been achieved without work. Perhaps an alternative could be to articulate the stillness haunting the mummified body and describe this lack of things happening as a feat of its own?

Instead of using the art gallery merely as a convenient and stimulating point of departure which presents us with various clues to other and at first glance more lively construction sites we could also take aim directly at the mutability of the body in front of us and the quiet spectacle which permits it to subsist alongside artefacts telling a more heterogeneous story. For the compositionist it might be more fruitful to pursue such an enquiry, venturing into the stillness and seemingly eternal presence of the exhibit. How is such stillness achieved? What could be learned from it with regards to the co-existence of vibrant and lively visitors on the one hand and mute, dead and stilled bodies on the other (see also Abrahamsson, 2010b)? The mummified body is neither an emergent 'fact' nor a controversy that has been settled. Rather, it is a bundle of organic matter that has been temporarily - or rather temporally - slowed down. As such, not only does it offer the empirical philosopher an intriguing and challenging contrast with the fast paced life of the city outside, or the intricate movements of visitors and staff in the gallery; it also conjures some interesting frictions vis-à-vis our other example.
By contrast, consider two ways in which one could try to craft a uniquely adequate account of flood risk. One option is to follow the daily practice of some of the experts who are frequently called upon by both the insurance industry and the Environment Agency (which is the responsible government body in the UK) to map out the extent and frequency of various hypothetical flood events. This is in many ways similar to following the multiple enactments of the mummified body except the practices which are now in the cross hairs tend to be spatially rather than temporally distributed: the work is both ongoing and frequently disputed.

One might for example try to follow the daily doings of flood modellers and describe how the English city and landscape is transformed into topographic images using remotely sensed data from satellites and airborne LiDAR (Light Detection and Ranging); how these images are modified to accommodate a simulated 'natural' flow of water across a virtual landscape by digitally weeding out penetrable or impermanent barriers such as cars, sheep, bridges or vegetation; or how these modified images (called Digital Terrain Models) are then divided into grid cells and fed into a piece of software capable of computing how water will flow from one cell to the next. This process, known as 2-dimensional hydraulic modelling, is typically used to simulate surface water flooding from rainfall runoff, a problem which has become increasingly costly to the insurance industry during the past decade (see also Munk, 2012).

Such a description is clearly calibrated by a desire to find out how flood risk is brought into being (it sets its sights on the construction of the object) and could very well support a strategy of interference since 2-dimentional hydraulic modelling is by no means the only practice with a 
stake in the production of flood risk. Alternatives include loss modelling (the translation of flood depths into financial impacts), catastrophe modelling (the translation of large, modelled event sets into aggregate probabilities of for example bankrupting an insurance company), or 1-dimensional hydraulic modelling (the translation of surveyed topographic data into a simulated flow of water in a river channel and an estimation of its potential overflows into an adjacent flood plain), not to mention the vernacular realisations of flood risk resulting, for example, from a homeowner's corporeal apprehensions amid clammy floorboards, lost property and disrupted routines.

To argue that these differences are not merely a matter of changing perspectives but of differing realisations of flood risk itself requires an attention to the specificities of their enactment. The objects constructed in 2-dimensional modelling could be described as the networked effects of things like hydrodynamic equations, satellites and graphic processing units; their sturdiness relies on the successful negotiation of questions like how to weigh the resolution of remote sensed imagery and the size of grid cells against the limits of computational power, or how to devise the guiding principles for the strip down of digital landscapes that enable simulated water to flow 'naturally' through them. As such, the way in which they are put together matters in very particular ways to discussions about insurance zoning and planning policy.

Crucially, other versions of flood risk rely on other translations for their effects, they must negotiate other kinds of questions for their sturdiness, and hence they will be sensitive to other issues, or matter to the same ones in different ways. Making explicit by way of descriptive marksmanship how these differences are not simply contenders for the position as 'the correct representation flood risk', but that they constitute distinct formats of reality would in itself be an accomplishment for the ontological guerrilla. The question, though, is what this type of account accomplishes if the strategic imperative is not per se to produce more mess but to craft a more liveable common world? What if we were to investigate what it takes to be risking a flood in a cosmopolitically correct manner and did not satisfy ourselves with an account of how different versions of flood risk are brought about?

Take some inspiration from the verbal meaning of risk: besides referring to some sort of object, it is also a way of doing things. Perhaps it is worth exploring what makes that particular 'regime of enunciation' (Latour, 2010b) different from, say, knowing something for a fact (Latour \& Woolgar, 1986), believing in it (Latour, 2005a) or rendering it as law (Latour, 2010c). A point here would be that risk cannot really exist as a tangible object like the ones described above (flood maps, probabilities, projected losses) and still be risky in and of itself. The presence of risk, Joost van Loon has argued, is 'always necessarily deferred'; it is 'a potential coming-intobeing, a becoming-real' (van Loon, 2002: 54).

The insurance industry, which is in the business of trading these potentials, provides an excellent laboratory for testing such a claim. Following a series of severe flood events between October and December 2000, several primary insurers repeatedly threatened to stop quoting in areas where floods had, to their minds, "become inevitable' (as one informant put it). Too much uncertainty kills off the gamble, but so does too much certainty. In an attempt to reintroduce a vital element of fortuity the Association of British Insurers set up the so called Statement of Principles under which 
government and local authorities committed to certain protection levels in return for a guarantee that homeowners could have their policies reinstated. The prospect of flooding could once again be shrouded in the right amount of uncertainty. While it is no doubt possible to describe how different knowledge practices bring different claims about flood risk into existence, such an enquiry does not account for the dynamics that keep these realisations from solidifying to a point where their presence is no longer deferred.

What is starting to emerge in both examples is a progressive expansion of the descriptive scope. Whereas the ontological guerrilla have to supply descriptions of multiple enactments of what appears to be one and the same thing in order to claim some sort adequacy vis-à-vis its strategic imperative, compositionism must add another layer in order to achieve something similarly sufficient. To be precise, it is the definition of a uniquely adequate account which must adapt and relate to the choice of strategy in order to have any real implication.

It is worth remembering here that while descriptive marksmanship is a long standing empiricist research tactic (see for example Latour and Woolgar's introduction to their anthropology of science, 1986: 27-33) it has not always formed part of an explicitly interventionist project. On the contrary, it was by proxy of descriptive accounts of the daily doings of science and technology (e.g. Callon, 1980; 1986; Latour, 1987; 1988) that a later focus on ontology developed. This early work took place under the tutelage of a different and now outmoded strategic imperative to which the purpose of description was neither to enact ontological multiplicity, nor to account for the heterogeneous constituency of a new and better common world, but to challenge the idea of a pre-existing realm of objects and a correspondencebased theory of truth. There has in other words been a change in strategy, a change which is aptly signalled in this sixteen year old passage by Annemarie Mol and Jessica Mesman:

Go and unravel the construction of an object. Any object! It doesn't matter what. The laws of gravity, a nuclear power plant or the HIV virus - anything will do. Just show that the thing doesn't exist by itself, but depends on something else. Which is true. But why repeat it? The only reason for doing so seems to be to undermine epistemology. Again. And again. And yet again. (Mol \& Mesman, 1996: 423)

Although the question is no longer whether or not something is constructed - a question which in Latour's mind has become 'irrelevant' (since long time settled: it always is) and replaced by the crucial question of whether or not something is 'well or badly constructed' (Latour, 2010a: 474) - a core part of empiricist marksmanship still consists in descriptively unravelling the construction of objects ${ }^{7}$.

In the hands of the ontological guerrilla this tactic has in a fairly straightforward manner been elaborated so that it covers ontological multiplicity, enabling its resulting accounts to be deemed adequate vis-à-vis a strategy of interference when they enact such multiplicities. Of course, if the dominant strategic imperative was still to 'undermine epistemology' (Mol \& Mesman, 1996: 423) we could have focused our energy entirely on a practice like 2-dimensional hydraulic modelling (in the case of flood risk) or forensic analysis using CT-scans (in the case of mummified bodies), and we could have assured ourselves that our manoeuvres had strategic relevance before we ever got around to accounting 
for alternative realisations. Compared to that, a strategy of ontological interference is already demanding an expansion of the descriptive scope: accounting for how an object is constructed is no longer adequate by default; its reality must also be multiplied.

In compositionist hands, however, further tactical elaboration seems to be needed in two important and perhaps not equally straightforward ways. Firstly, it can no longer be assumed that the goal alone is to unravel constructs (even if this leads to a multiplication of the real). This is clear in the case of flood risk where the enactment of things that carry that label can only partially account for the way in which floods are risked: an adequate account would have to be calibrated by the broader event in which these constructs can be maintained somewhere in between solid objectivity and its antipode (prevented, in a sense, from becoming facts). Besides the Statement of Principles and the way in which it hardwires planning policy guidelines and spending reviews into the political ecology of flood insurance, such an account might for example also include the way in which actual flood events unfold in new and surprising ways and the continuous reconfigurations of the issue that result from this constant suspension of certainty. It is also clear in the case of the mummified body where the description would be calibrated by the silent event unfolding in the art gallery, instead of being restricted to different constructions of the body as an object of a set of temporally distributed knowledge practices.

Secondly, even though the descriptive scope is thus expanded, there is still the question of cosmopolitical correctness which needs to be addressed if the idea of adequacy is to have any real currency in the compositionist camp. Once a description has been crafted, once the heterogeneous constituency has been listed, we have to ask ourselves if, or to what extent, this contributes to a more livable common world? How do we do that? Descriptive marksmanship will not help us here; we need some kind of normative protocol by which to proceed. This takes us to the last of the tactical tenets which has to do with the way we handle descriptive accounts (what we do with them; how we talk about them) once they have been brought about.

\section{Target Recognition: What to do with Descriptions?}

The third tactical tenet is less clearly defined and is not really an explicit part of the received wisdom on how to conduct ourselves as empirical philosophers. Indeed, 'tenet' might be the wrong word for it altogether.

Nevertheless, it can be seen as our attempt to put a name to a de facto recurrence in empiricist research practice, a recurrence which in spite of its ambiguity seems more and more crucial to the strategic face-off we engage in this paper. We could call it target recognition, and it has to do with the afterlife of the uniquely adequate account; the way we frame it; the operations it performs. In his review of Latour's now famous ethnography of a pedological field trip to the Boa Vista forest (Latour, 1999), Michael Lynch wondered what would have been lost if the otherwise clear account of the way in which a group of scientists manage to reduce the cacophony of a rainforest into a scientific statement had been left without the addition of 'abstract models of referential 'elements' arranged in chains' (Lynch, 2001: 230)? Denoted is a latent conflict with the pledge to keep open the conditions of possibility. Such abstractions (and the circulating reference diagram is a powerful example of that) easily come to serve as 'useful' guidelines for subsequent descriptions of other 
practices. What we want to argue here is that while this practice of subsuming specificities under more abstract headlines has its problems - especially to the ontological guerrilla - there are also ways in which interventionist research - and especially compositionism - cannot do without it.

Latour, for instance, does not only provide descriptions, he also orders whatever he is describing under more abstract headings like 'modes of existence' (e.g. Latour, 1999: 157; 2007) or 'regimes of enunciation' (Latour, 2005b: 241n, 2005a); and Law does not only attend to messy specificities but discerns in them different 'modes of ordering' (Law, 1994) or different 'modes of mattering' (Law, 2004b). It is not difficult to see the potential problem, recalling for example that under no circumstances should a "practice be defined as "like any other" (Stengers, 2005: 184), but at the same time these abstractions play key roles in both of the interventionist strategies under consideration in this paper. To the compositionists they provide the normative standards for distinguishing particular types of constructions as being more or less successfully carried out; to the ontological rebels they facilitate the idea that there is more than one way of being politically relevant. How does that relate to our two examples?

The latter first: to make the claim that what goes on in the art gallery is a form of 'interference' (according to John Law (2004b) a mode of mattering distinguishable from, say, 'critique' or 'puzzle-solving') seems to play an important role in the collective formulation and articulation of a specific strategy for intervention. The abstraction helps us recognize a similarity in purpose across a wide spectrum of accounts crafted to the unique particularities of what would appear to be very different situations. Thus, an account that mul- tiplies the reality of a controversial object like flood risk can be likened to, and compared with, an account of the way a mummified body is exhibited alongside devices of its disparate enactments. The only reason why these two examples can be made to speak to one another in a discussion about the practical pronunciation of different interventionist strategies is that an abstract model - in this case a particular mode of mattering - has been logged in our targeting systems. Suddenly, similarity can be acknowledged in specificities.

Then the former: to think about the role of some describable practice for the greater good of a not yet realized collective is not easily done without some level of abstraction. Latour tells us, for example, that while the contribution of scientists will be to 'give perplexity the formidable asset of instruments and laboratories, which will allow it to detect scarcely visible phenomena very early' (Latour, 2004b: 137), the contribution of moralists will be to remind the rest of us 'that the collective is always a dangerous artifice' (Latour, 2004b: 157); that our task is to help religion, politics, science and economics to 'sing again in their right respective keys' (Latour, 2010b: 607); and that we should neither forget that there is a difference, for example, between existing as a living horse ('subsistence') and a specimen in the hands of evolutionary scientists ('reference'), nor that there are many more possible 'modes of existence' (Latour, 2007: 24). Thus, while the mummified body is no doubt a specimen of various sciences, and its existence conditioned on various chains of reference, it is also a dead object which subsists (even though it might do so in a radically different way than the horse struggling to survive). Equally, while flood risk represents a multiplicity of scientific phenomena with different referential 'blood flows' (Latour, 1999: 80), it could also be argued that 'risk' 
should be considered a separate mode of existence which differs in important ways from the referential enunciation of facts.

We seem to be getting to the crux of the strategic discord here. While Latour has explicitly stated his ambition to describe and compare regimes of enunciation across the spectrum, Law keeps to the position that 'what counts as beauty can neither be determined in general, nor out of context' (Law, 2004a). We want to argue that this dissonance can be traced to their strategic positions and can be taken as a sign that they have 'gone with the army to the field to arrange particulars' (Clausewitz, 2008: 147). The compositionist desire to craft a new sense of cosmopolitical correctness becomes an impossible enterprise if we cannot find ways of making our descriptions do a more abstract job than 'merely' accounting for specificities. We might for example want to think about the virtues of exhibiting the mummified body in both its referential modes and its peculiar form of subsistence, or we might consider treating the unsettling existence of flood risk and its symbiotic relationship with controversy as something to be cared about and valued for its ability to 'spark a public into being' (Marres, 2005). In either case, there is no way around abstractions if that enterprise is to be engaged with any significance.

\section{Ceasefire}

This paper relies on a caricature. In fact, it relies on two caricatures. Firstly, it lumps 30 years of empirical philosophy within the field of STS under three crude strategic agendas: a showdown with epistemology succeeded by two different interventionist imperatives, namely that of the ontological guerrilla and that of the compositionist international. Secondly, it pits compositionism and ontological interference sharply against each other and although it is not the first to do so (see especially Law, 2009) the picture is more complicated than that. Bruno Latour is still preoccupied with the enactment of multiplicity - indeed, that is in many ways what good cosmopolitics is supposed to do (e.g. Latour, 2004d) - although he feels the need to devise a framework, a new and comprehensive common world with due process and a constitutional order to support it. And while John Law proclaims that 'rules and procedures do not actually rule' and that 'in practice the world is irredeemably messy' (Law, 2009: 5) he still talks of a diversity of political 'goods' ('truth' being one of them, depending on the context) and of our responsibility to consider these as part of our interventions (Law, 2004a: 148-151). What we hope to have crystallized by forcing a sharply drawn opposition on this debate is a fundamental difference between two prominent visions for the future of empirical philosophy in STS. The point of this exercise has been to establish a basis for reflecting on the consequences these differing visions can have for the more mundane or tactical choices that make up an empiricist intervention.

We have deliberately tried to suspend judgement, painfully aware that no such thing is possible in practice. Our ambition has been to highlight a friction on the commanding level of empiricist STS and relate it to some of the practical problems we have grappled with when trying to do doctoral research within that tradition. In the resulting discussion we have argued that there are no watertight shutters between the descriptive craft of the uniquely adequate account and the various aspirations concerning the political effect of such accounts. Instead we have suggested that the relationship bears some similarity to that of strategy and tactics: even though there is a difference between good marks- 
manship and an overall plan for the war effort, neither aspect can be very effective in practice without taking the other firmly into account. Arguably, there are a number of alternative metaphors which fit that bill, but what we find particularly attractive about the belligerent spin of strategy and tactics is both the notion of an ontopolitical battlefield in which all interventions (including those of the empirical philosopher) must abide by the same basic rules, as well as the practical recognition that a strategic agenda, in order to have any impact, must always be fielded alongside the various tactical manoeuvres making up a campaign.

So the ambition was not to take sides but to explore what the contending plans for interventionist empirical philosophy could possibly mean for the local skirmishes in which we are engaged. In doing so a certain need for strategic reflexivity on the level of the empiricist foot soldier has become clear. Good questions do not simply leave open the conditions of possibility: it must be taken into consideration what we are keeping them open for; what it is we are trying not to condition. Equally, good descriptions do not simply provide uniquely adequate accounts: it must also be taken into consideration what adequacy means vis-a-vis the strategic imperative under which we intervene. And finally we must consider that even the most uniquely adequate account may have to be abstracted in various ways in order for it to become relevant to strategy - even though it fundamentally disagrees with some core virtues of empiricist research tactics.

While we both agree and disagree with points raised by both of our two strategic interlocutors (and while we also agree and disagree between each other on these points), it is no doubt easier to artificially suspend judgement in a text like this than it is to do so in practice. We have tried to stay out of it, and arguably that sits somewhat uneasily with the theme of intervention. Signe Vikkelsø has convincingly voiced the idea that a good description is one that 'puts itself at risk by being exposed to a multiple audience, and that at the same time is sensitive to the ways it puts others at risk' (Vikkelsø, 2007: 298), and perhaps it is fitting to add if only a tinge of that kind of sensitivity before we withdraw. Take the example of flooding: here it was clearly, and sometimes obstructively, felt that description is not a neutral activity. On the contrary, it matters immensely to the stakeholders how the issue is accounted for, a fact which becomes clear no matter whether one is dealing with government agencies, insurance companies, modelling consultancies or homeowners which are all frequently contesting the way in which the others define, perceive and inform the problem $^{8}$. And although the mummified body is arguably somewhat less controversial, we both repeatedly experienced that the research questions we fielded became matters of concern to the practitioners we were engaging with. Indeed, part of the motivation for writing this paper stems from this shared experience of ongoing redefinition which forced us to continuously rethink what we were trying to achieve.

Thus, interventionist tactics could also amount to learning to become tactful, about becoming attentive to a situation as it evolves, and adapting as it does so. It could be about care as opposed to choice (Mol, 2008), or about putting yourself at risk and letting others intervene with what you are trying to do (Whatmore, 2003; following Stengers, 1997). Here, we have risked at least two things: First, we have jeopardized our strategic interlocutors in the sense that we have forced them to discuss our examples through two caricatures. Second, we have attempted to suspend judgement something we both acknowledge is impossible in practice - and by doing so we have 
invariably betrayed the ongoingness of our projects. But, we would argue, it is in this impossible space of neutrality that differences and discords become tangible and open for discussion.

\section{Acknowledgements}

For their insightful and thought provoking comments we would like to thank Morten Krogh Petersen, Marie Sandberg, Carina Ren and Astrid Pernille Jespersen on the editorial board of this special issue, our two anonymous reviewers, Sarah Whatmore at the University of Oxford, Torben Elgaard Jensen and Joakim Juhl at the Technical University of Denmark, and Filippo Bertoni, Rebeca Ibanez and Emily Yates-Doerr at the University of Amsterdam.

\section{References}

Abrahamsson, S. (2010a) Something Happening: On the Geographies of a Mummified Body, D.Phil. thesis, (Oxford: University of Oxford).

Abrahamsson, S. (2010b) 'Stillness, ReAnimated. Experiencing Body Worlds and the Work of Art', in D. Bissell and Fuller, G (eds), Stillness in a Mobile World. (London: Routledge): 155-171.

Callon, M. (1980) 'Struggles and Negotiations to Define What is Problematic and What is not: the Sociology of Translation', in K.D. Knorr, R. Krohn and R.D. Whitley (eds), The Social Process of Scientific Investigation: Sociology of the Sciences Yearbook (Dordrecht: Reidel): 197-219.

Callon, M. (1986) 'Some Elements of a Sociology of Translation: Domestication of the Scallops and the Fishermen of Saint Brieuc Bay' in J. Law (ed), Power, Action and Belief: a New Sociology of Knowledge? (London: Routledge): 196233.

Clausewitz, C.V. (2008) On War (Radford: Wilder).
Cohen, B.R. \& Galusky, W. (2010) 'Guest Editorial', Science as Culture 19(1): 1-14.

Collins, H. \& Evans, R. (2002) 'The Third Wave of Science Studies: Studies of Expertise and Experience', Social Studies of Science 32: 235-296.

Collins, H. \& Evans, R. (2007) Rethinking Expertise (Chicago: Chicago University Press).

Gad, C \& Bruun Jensen, C. (2010) 'On the Consequences of Post-ANT', Science, Technolgoy and Human Values, 35(1): 55-80.

Haraway, D. (1988) 'Situated Knowledges: The Science Question in Feminism and the Privilege of Partial Perspective,' Feminist Studies 14(3): 575-599.

Haraway, D. (1989) Primate Visions: Gender, Race and Nature in the World of Modern Science (London: Routledge).

Haraway, D. (1991) 'A Cyborg Manifesto: Science, Technology and Socialist Feminism in the Late Twentieth Century' in D. Haraway (ed), Simians, Cyborgs and Women: the Reinvention of Nature (London: Free Association Books): 149181.

James, W. (1987) Writings 1902-1910 (New York: The Library of America).

Lane, S.N., Landström, C. \& Whatmore, S. (2011) 'Imagining flood futures: risk assessment and management in practice', Philosophical Transactions of the Royal Society, 369(1942): 1784-1806.

Lane, S.N., Odoni, N., Landström, C., Whatmore, S., Ward, N. \& Bradley, S. (2011) 'Doing flood risk science differently: an experiment in radical scientific method, Transactions of the Instititute of British Geographers, 36: 1536.

Latour, B. (1987) Science in Action - How to follow scientists and engineers through society (Milton Keynes: Open University Press). 
Latour, B. (1988) The Pasteurization of France (Cambridge MA: Harvard University Press).

Latour, B. (1999) Pandora's Hope - Essays on the Reality of Science Studies (Cambridge MA: Harvard University Press).

Latour, B (1999a) 'On Recalling ANT' in J. Law and J. Hassard (eds), Actor-Network Theory and After (Oxford: Blackwell): 1525.

Latour, B. (2003) 'Why has critique run out of steam? From matters of fact to matters of concern', Critical Inquiry 30: 225-248.

Latour, B. (2004a) 'How to Talk About the Body? The Normative Dimension of Science Studies, Body \& Society 10(2): 205-229.

Latour, B. (2004b) Politics of Nature (Cambridge MA: Harvard University Press).

Latour, B. (2004c) 'A prologue in form of a dialog between a Student and his (somewhat) Socratic Professor' in C. Avgerou, C. Ciborra and F.F. Land (eds), The Social Study of Information and Communication Study (Oxford: Oxford University Press): 62-76.

Latour, B. (2004d) 'Whose Cosmos, Which Cosmpolitics? Comments on the Peace Terms of Ulrich Beck', Common Knowledge 10(3): 450-462.

Latour, B. (2005a) 'Thou Shall Not FreezeFrame' or How Not to Misunderstand the Science and Religion Debate' in J.D. Proctor (ed), Science, Religion, and the Human Experience, , Oxford University Press, Oxford: 27-48.

Latour, B. (2005b) Reassembling the Social - An Introduction to Actor-NetworkTheory (Oxford: Oxford University Press). Latour, B. (2007) 'A Textbook Case Revisited: Knowledge as Mode of Existence' in E. Hacket, O. Amsterdamska, M. Lynch \& J. Wacjman (eds), The Handbook of Science and Technology Studies, Third ed, (Cambridge MA: MIT Press): 83-112.
Latour, B. (2010a) 'An Attempt at Writing a Compositionist Manifesto', New Literary History 41: 471-490.

Latour, B. (2010b) 'Coming out as a philosopher', Social Studies of Science 40(4): 599-608.

Latour, B. (2010c) The Making of Law: An Ethnography of the Conseil d'État (Cambridge: Polity Press).

Latour, B. \& Woolgar, S. (1986) Laboratory Life - The Construction of Scientific Facts (Princeton NJ: Princeton University Press).

Law, J. (ed) (1991) A Sociology of Monsters: Essays on Power, Technology, and Domination (London: Routledge).

Law, J. (1994) Organizing Modernity (Oxford: Blackwell).

Law, J. (2004a) After Method - Mess in Social Science Research (Abingdon: Routledge).

Law, J. (2004b) 'Matter-ing, Or How Might STS Contribute?', Centre for Science Studies, Lancaster University, draft available at

http://www.heterogeneities.net/ publications / Law2009TheGreerBushTest.pdf, accessed on December $5^{\text {th }}$, 2010: 1-11.

Law, J. (2009) 'The Greer-Bush Test: on Politics in STS, draft available at http:// www.heterogeneities.net/publications/ Law2009TheGreer-BushTest.pdf, version of December 23rd 2009, accessed on August $10^{\text {th }}, 2010$.

Lee, N. \& Brown, S. (1994) 'Otherness and the actor-network: the undiscovered continent', American Behaviroal Scientist 37: 772-790.

Lynch, M. (2001) 'A Pragmatogony of Factisches', Metascience 10(2): 223-231.

Marres, N. (2005) 'Issues Spark a Public into Being: A Key But Often Forgotten Point of the Lippmann-Dewey Debate' in B. Latour and P. Weibel (eds), Making Things Public - Atmospheres of Democracy (Cambridge MA: MIT Press): 208-217. 
Massey, D. (2003) 'Imagining the field' in M. Pryke, G. Rose and S.J. Whatmore (eds), Using Social Theory - Thinking through Research (London: SAGE Publications).

Mesman, J. (2007) 'Disturbing Observations as a Basis for Collaborative Research', Science as Culture 16(3): 281-295.

Mol, A. (1999) 'Ontological Politics: A Word and Some Questions' in J. Law and J. Hassard (eds), Actor Network Theory and After (Oxford: Blackwell): 74-89.

Mol, A. (2002) The Body Multiple - Ontology in medical practice (London: Duke University Press).

Mol, A. (2008) The Logic of Care; Health and the Problem of Patient Choice (Abingdon, Oxon: Routledge)

Mol, A. (2010) 'Actor-Network Theory: sensitive terms and enduring tensions', Kölner Zeitschrift für Soziologie und Sozialpsychologie 50: 253-269

Mol, A. \& Mesman, J. (1996) 'Neonatal food and the politics of theory: some questions of method', Social Studies of Science 26(2): 419-444.

Moser, I. (2008) 'Making Alzheimer's Disease Matter: Enacting, Interfering and Doing Politics of Nature', Geoforum 39: 98-110

Munk, A. (2010) Risking the Flood: Cartographies of Things to Come, D.Phil. thesis (Oxford: University of Oxford).

Munk, A. (2012) 'Anticipating natures: what the flood apprentice learned from a modelling tutorial', in K. Hastrup and M. Skrydstrup (eds), The Social Life of Climate Models (London: Routledge).

O'Doherty, O. (1986) Inside the white cube: the ideology of the gallery space (San Fransisco CA: Lapsis Press).

Petrie, F. (1889) Hawara, Biahmu, and Arsinoe (London: Field \& Tuer).

Rose, M. (2002) 'Landscape and labyrinths', Geoforum 33(4) 455-467.

Star, S.L. (1991) 'Power, technologies and the phenomenology of conventions: on being allergic to onions' in J. Law (ed), A Sociology of Monsters: Essays on Power, Technology and Domination (London: Routledge).

Stengers, I. (1997) Power and Invention - Situating Science (Minneapolis: University of Minnesota Press).

Stengers, I. (2003a) Cosmopolitiques I (Paris La : Decouverte).

Stengers, I. (2003b) Cosmopolitiques II (Paris: La Decouverte).

Stengers, I. (2005) 'Introductory notes on an ecology of practices', Cultural Studies Review 11(1) 183-196.

Van Loon, J. (2002) Risk and Technological Culture - Towards a Sociology of Virulence (London: Routledge).

Vikkelsø, S. (2007) 'Description as Intervention: Engagement and Resistance in Actor-Network Analyses, Science as Culture 16(3): 297-309.

Weibel, P. \& Latour, B. (2007) 'Experimenting with Representation: Iconoclash and Making Things Public' in S. Macdonald and P. Basu (eds), Exhibition Experiments (Oxford Blackwell): 94-108.

Whatmore, S. (2003) 'Generating Materials' in S. Pryke, Rose, G. and S. Whatmore (eds), Using Social Theory (London: Sage): 89-104.

Whatmore, S. (2009) 'Mapping Knowledge Controversies: Science, Democracy and the Redistribution of Expertise, Progress in Human Geography 33(5): 587-598.

Zuiderent-Jerak, T. \& Jensen, C.B. (2007) 'Editorial Introduction: Unpacking 'Intervention' in Science and Technology Studies', Science as Culture 16(3): 227235.

\section{Notes}

1 As one of the reviewers of this paper pointed out, our main concern here is actually with actor-network theory, and not with STS. While we agree with this 
point, we choose to use the different term empirical philosophy - a smaller umbrella - to describe our main interlocutors. For three illuminating critiques of the term actor-network theory see Gad \& Bruun Jensen, 2010; Latour, 1999a and Mol, 2010.

2 There are probably several ways of dating this, but we take the publication of the edited volume 'A Sociology of Monsters: Essays on Power, Technology and Domination' (Law, 1991) as a useful marker.

$3 \mathrm{He}$ thus rhetorically lumps Latour's project with that of Harry Collins and Robert Evans (2002; 2007), although he recognizes the otherwise very limited similarity.

4 We have chosen to narrow down our interlocutors to mainly two so as to be able to crystallize what we consider to be a significant difference. Perhaps we are then reifying the two positions that are under scrutiny without looking at how and where they travel, or how they are translated as they do so. Our main point, however, is exactly that they travel and so inevitably make their mark on interventionist research within empirical philosophy.

5 While the use of war metaphors in STS has been critiqued, and is by now largely abandoned, we would argue that it is not so much war itself that we are interested in but rather the ontopolitical differences between strategy and tactics in any conflict.

6 In a sense the approach we have taken to intervention in this paper makes it somewhat meaningless to talk about a piece of research which is not by impli- cation interventionist. What we are trying to highlight here, however, are not the various ways in which a specific piece of analysis can (or cannot) be thought of as an intervention, but the various motivations one might have for carrying out that analysis in different ways.

7 With this we do not want to suggest that the issue of construction is irrelevant tout court, but rather that a lot has happened since the period in time when (social) construction was topical. What has happened is a shift in the terms under which the concept is deployed.

8 Indeed, the doctoral studentship formed part of the interdisciplinary RELUfunded 'Understanding Environmental Knowledge Controversies' project which comprised an explicitly actionoriented interventionist agenda under which flood-stricken local publics were engaged through experiments with different ways of doing flood science (see for example Whatmore, 2009; Lane, Landström \& Whatmore, 2011; Lane et al., 2011)

\section{Anders Kristian Munk}

Section for Innovation and Sustainability, Technical University of Denmark

Produktionstorvet Bygning 424, 2800 Kgs. Lyngby Denmark ankm@dtu.dk

Sebastian Abrahamsson

AISSR, Department of Sociology and Anthropology, University of Amsterdam Kloeveniersburgwal 48, 1012 CXAmsterdam The Netherlands c.s.abrahamsson@uva.nl 